\title{
Overview of pond aquaculture in Nepal
}

\section{Bidika Subedi $^{1 *}$, Abhimanyu Shrestha ${ }^{2}$}

\author{
1*Agriculture and Forestry University, Chitwan, Nepal \\ ${ }^{2}$ Research Assistant, Fishery research station, Trishuli, Nuwakot, Nepal \\ *Corresponding Author
}

\begin{abstract}
Pond aquaculture is the foremost contributor to the aquaculture contributing 80.25\% $(58,433 \mathrm{mt}$. tonnes) to the total aquaculture production in fiscal year 2017/18. There are 44,722 ponds covering 11895.31 ha area in Nepal with the productivity $4912 \mathrm{~kg} / \mathrm{ha}$. Among, the different agro-ecological region, terai region is the main contributor to aquaculture as large number of ponds covering the highest area are located in this region. The highest production of pond aquaculture is from Province-2 followed by province-5. The various challenges faced by the farmers in Nepal are lack of technical knowledge, lack of sustainable fingerling supply system and lack of infrastructure development related to fish farming due to less priority of government in fisheries sector. Hence, the government should develop the plan and policy to disseminate the technical knowledge among fish farmers, management of fingerlings production and supply channel at the community level.
\end{abstract}

Keywords-Aquaculture, pond, Nepal, production.

\section{INTRODUCTION}

Aquaculture is one of the most promising means of intensifying the utilization of natural water resources and hence improving the conditions in the rural areas of Nepal (Katz, 1987). Being landlocked country, Nepal is deprived of any oceanic resources due to which it depends only on inland aquaculture with finfish farming. The total production of fish in Nepal is $86,544 \mathrm{mt}$.tonnes out of which aquaculture contributes $75.54 \%$ (65,544 mt.tonnes) in fiscal year 2017/18 (CFPCC, 2018). Aquaculture is increasing rapidly in Nepal with the average annual growth rate of $4.21 \%$ which contributes $1.12 \%$ to Gross Domestic Product and $4.18 \%$ to Agricultural Gross Domestic Product in fiscal year 2017/18 (CFPCC,2018). Aquaculture practices that contributed to fish productions in Nepal are pond culture, rice cum fish culture, ghol culture, enclosure culture, pen culture, rainbow trout culture and government farm centre. Pond culture is a very popular aquaculture practice with many aquatic species cultured in the pond. Out of all the aquaculture practices, pond culture is the major contributor which alone generated $80.25 \%(58,433 \mathrm{mt}$.tonnes) of total aquaculture production in Nepal (CFPCC, 2018). Chinese carps and Indian major carps are the dominant species in pond aquaculture which are generally stocked under polyculture. However, the monoculture of Common carp, tilapia and pangasius has also been reported (Mishra,2015). The contribution of various aquaculture practices to total aquaculture production is shown below in the table 1:

Table 1: Contribution of various aquaculture practices to total aquaculture production (CFPCC, 2018)

\begin{tabular}{|l|l|}
\hline Aquaculture practices & Production(mt. tonnes) \\
\hline Pond culture & 58,433 \\
\hline Rice cum fish culture & 15 \\
\hline Ghol culture & 6,390 \\
\hline Enclosure culture & 65 \\
\hline Cage & 302.28 \\
\hline Rainbow trout & 320 \\
\hline Government farm & 18.8 \\
\hline Total & 65,544 \\
\hline
\end{tabular}

History of aquaculture in Nepal is about 80 years which is considered relatively short compared to other aquaculture developed countries of south and south-east Asia (Shrestha, 2015). Aquaculture in Nepal began in the 1940s with pond culture of Indian major carps. Further development began in the 1950s with the introduction of exotic species common carp (Cyprinus carpio) whose breeding success in the 1960s 
followed by monoculture practices and gained considerable popularity in private sector (FAO, 2005). More significant progress was seen in the 1970s with the introduction and farming of three exotic Chinese carp species : silver carp (Hypophthalmichthys molitrix), bighead carp (Aristichthys nobilis) and grass crap (Ctenopharyngodon idellus) and their successful breeding in the captivity. Similarly, the induced breeding of three commercial valuable indigenous major carps: rohu (Labeo rohita), mrigal (Cirrhinus mrigala) and catla (Catla catla) were successfully established which was followed by polyculture system of production in the ponds with seven species of fish with different habits (FAO, 2005). Although the aquaculture begin earlier, the aquaculture production was recorded only from 1966 with only $3 \mathrm{mt}$. tonnes of fish production (Mishra, 2015).

\section{CATEGORIZATION OF POND AQUACULTURE}

In Nepal, pond aquaculture has been categorized into extensive, semi-intesive and intensive farming (Mishra, 2015). The different farming system are illustrated below (Shrestha and Pandit, 2017):

\section{1) Extensive farming}

In this farming system, fish are stocked in density of 7000 fish/ha in large ponds measuring 1-5 ha. The fish are reared with no supplemented feed and fertilizer and yield is low i.e. 1-2 ton/ha/yr.

\section{2) Semi-intensive farming}

In this farming system, fish are stocked in the density of 7000-10000 fish/ha in relatively small ponds 0.2-0.5 ha. Care is taken to develop natural foods by fertilization and feed are supplemented and the yield is moderate i.e. 3-6 ton/ha/yr. It is the most common farming method practiced in Nepal.

\section{3) Intensive farming}

In this farming, fish are stocked at the density of 10-15 fish $/ \mathrm{m}^{3}$ of water in small ponds. Complete formulated feed are supplied and the yield is high i.e. 15-100 ton/ha/yr.

\section{TRENDS OF POND AQUACULTURE IN NEPAL}

Pond culture is the dominant aquaculture practice among various culture practices and is increasing rapidly.

\section{1) Expansion of pond area}

From the fiscal year 2001/02 to 2017/18, ponds have been constructed in 5,941 ha for aquaculture. From the below figure-1, the pond area in the fiscal year 2008/09 is decreased because of the consequences of natural disasters(flood) that damaged many fish ponds in terai region (Kunwar and Adhikari, 2017). The highest area of pond constructed was achieved in fiscal year 2016/17 (1461.6 ha)

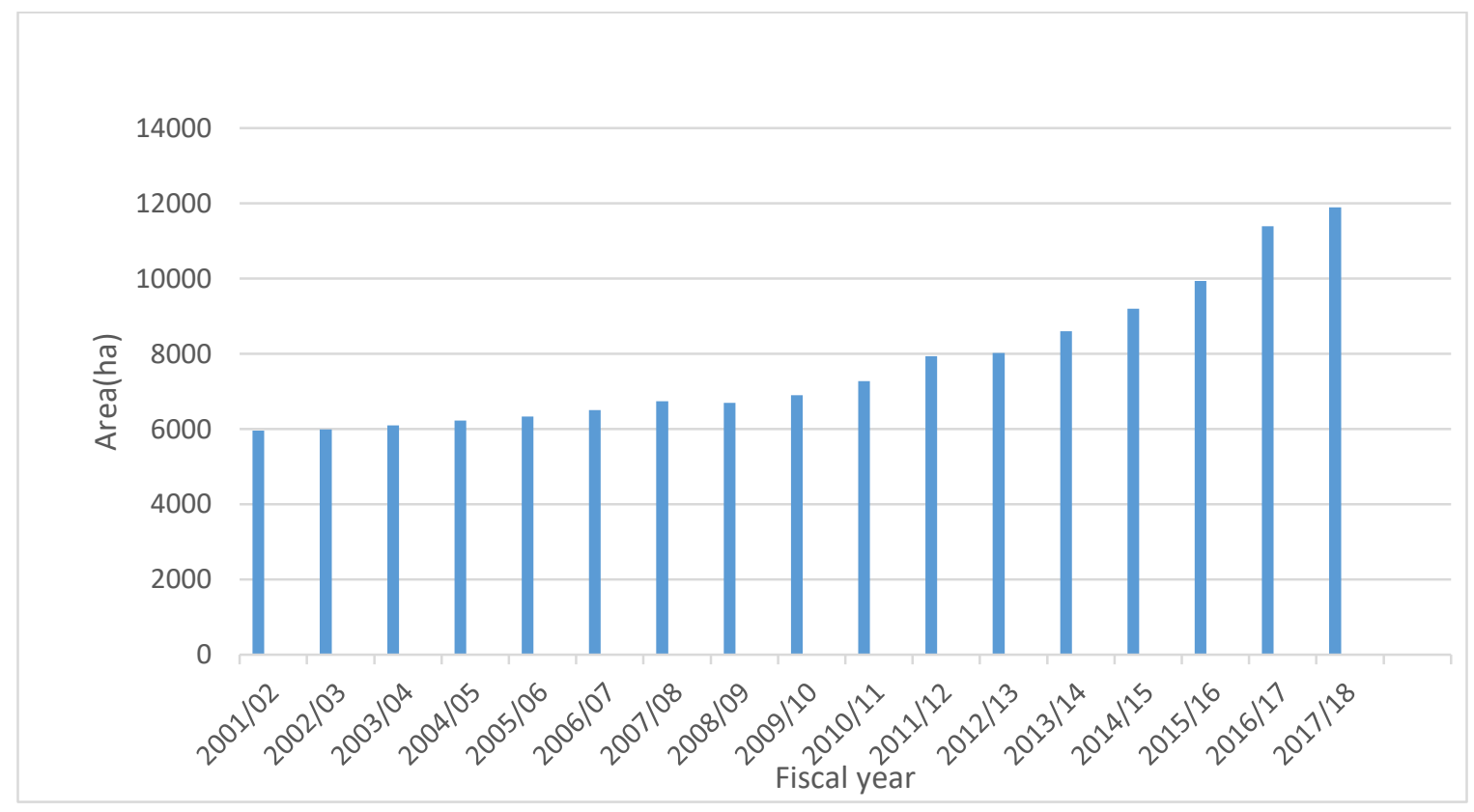

Fig.1: Expansion of pond area (CFPCC, 2018) 


\section{2) Pond production}

From the figure-2, we can conclude that the fish production from the pond increases annually. Significant improvement of fish production was recorded in the fiscal year 2016/17 because in the same fiscal year highest area of pond constryction was achieved. In the last eighteen years, fish production from the pond aquaculture was increased by 47,209 mt. tonnes mainly due to the both horizontal and vertical expansion of pond aquaculture practice and pond productivity.

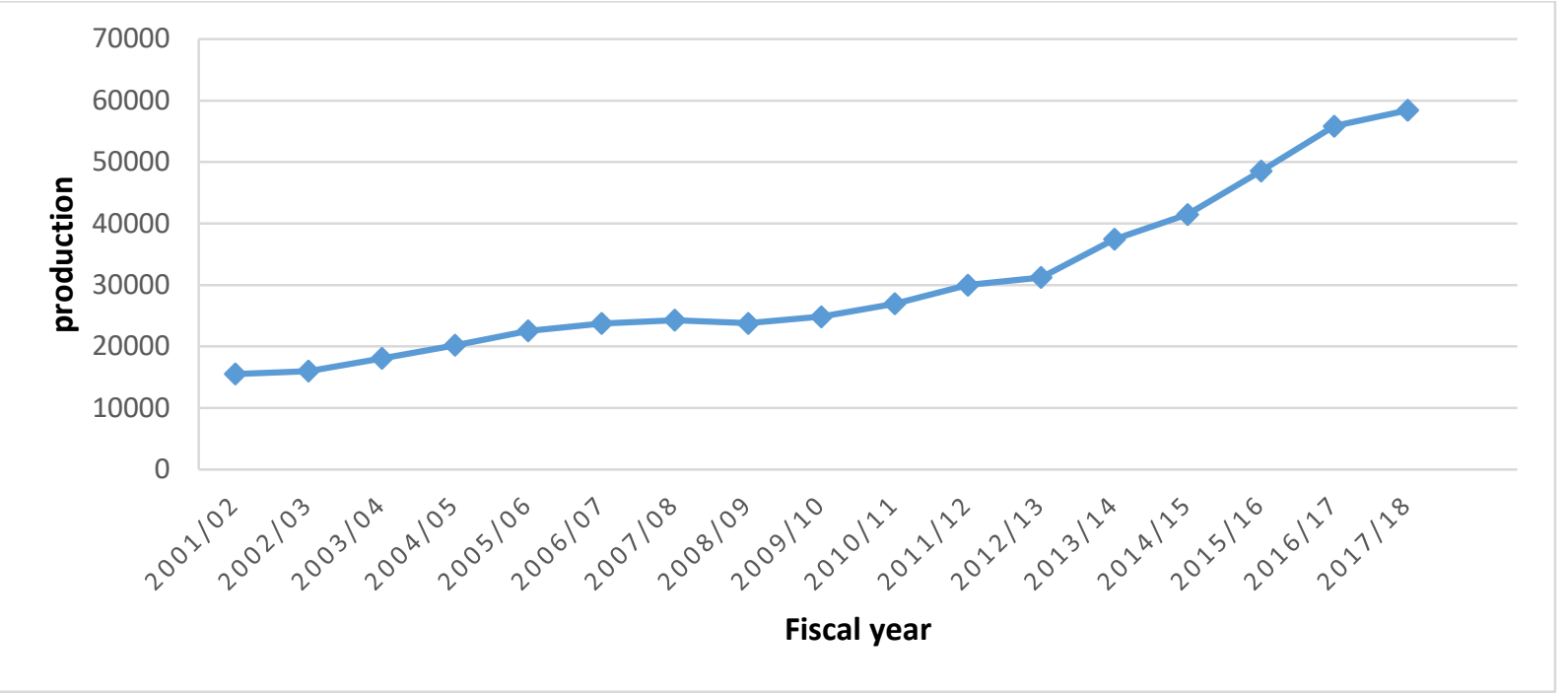

Fig.2: Fish production from pond (CFPCC, 2018)

\section{3) Pond productivity}

Pond productivity was only $2.61 \mathrm{mt}$. tonnes/ha in fiscal year $2001 / 02$ which is increased to 4.91 in $2017 / 18$ as shown in the figure-3. This incresed productivity of fish pond has significant impact on national fish production. The reasons for the increased productivity are improvement in technology, mechanization in fish farming system, good management practices and policy of government for the improvement of fish production (Kunwar and Adhikari, 2017).

\section{Chart Title}

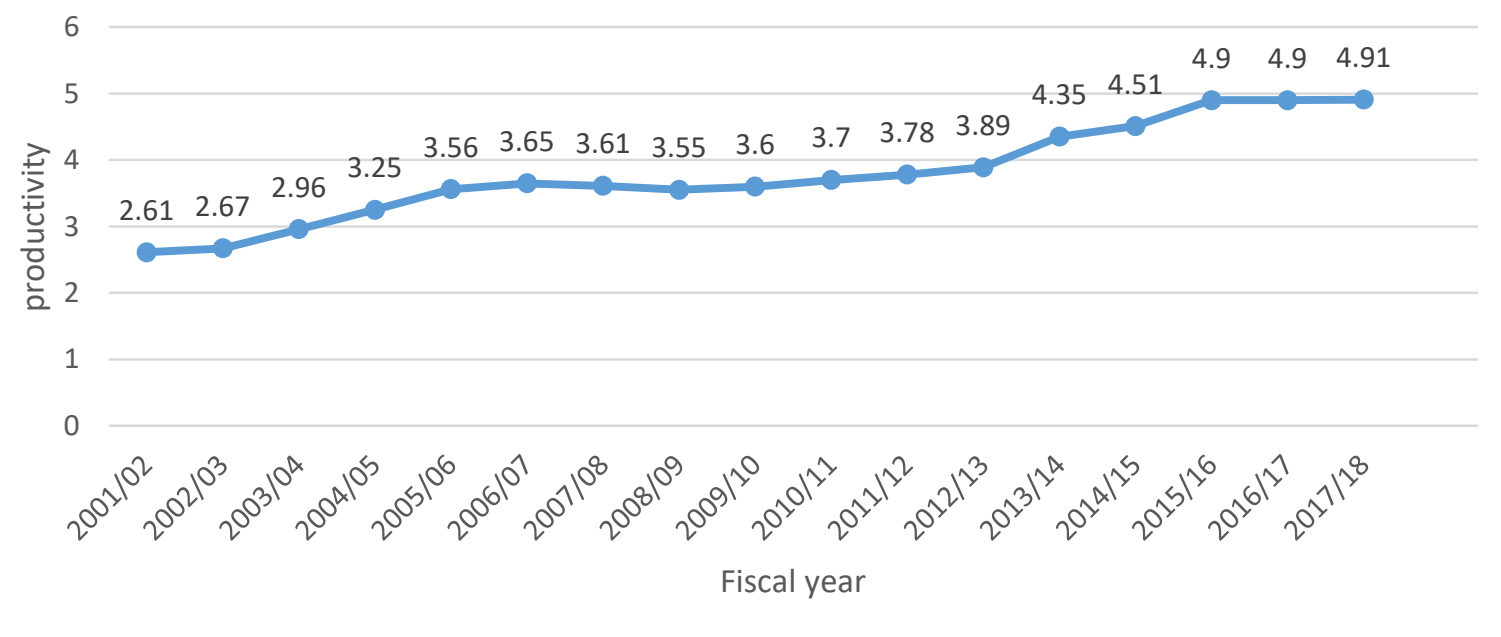

Fig.3: Productivity of fish pond (CFPCC, 2018) 


\section{4) Distribution of Pond}

Nepal is agro-ecologically divided into three regions i.e. Terai, hilly and himalayan. The pond aquaculture is highest in the terai region which may be due to the suitability of land area and well-developed infrastructure in terai region compared to other. Terai region consists of $80.25 \%(44,722)$ of total number of ponds and $88.76 \%$ (11895.31 ha) of total area covered by ponds in fiscal year 2017/18 (CFPCC, 2018). Nepal is divided into seven federal provinces by the constitution of Nepal adopted on 20 September, 2015 before that it was divided into five development regions. The province wise distribution of pond, pond production and productivity is listed in the table -2 :

Table 2-Province wise distribution of pond in Nepal (CFPCC,2018)

\begin{tabular}{|l|l|l|l|l|}
\hline \multirow{2}{*}{$\begin{array}{l}\text { Provin } \\
\text { ce }\end{array}$} & \multicolumn{4}{|c|}{ Information on pond } \\
\cline { 2 - 5 } & $\begin{array}{l}\text { Numbe } \\
\mathrm{r}\end{array}$ & $\begin{array}{l}\text { Area(ha } \\
\text { ) }\end{array}$ & $\begin{array}{l}\text { Productio } \\
\mathrm{n}(\mathrm{kg})\end{array}$ & $\begin{array}{l}\text { Productivi } \\
\text { ty(kg/ha) }\end{array}$ \\
\hline $\begin{array}{l}\text { Provinc } \\
\text { e-1 }\end{array}$ & 7,751 & $1,517.6$ & $7,485,029$ & 4,932 \\
\hline $\begin{array}{l}\text { Provinc } \\
\text { e-2 }\end{array}$ & 17,428 & $6,606.8$ & $33,746,394$ & 5,108 \\
\hline $\begin{array}{l}\text { Provinc } \\
\text { e-3 }\end{array}$ & 3,795 & 638.26 & $3,004,765$ & 4,708 \\
\hline $\begin{array}{l}\text { Provinc } \\
\text { e-4 }\end{array}$ & 2,093 & 273.26 & $1,167,411$ & 3,989 \\
\hline $\begin{array}{l}\text { Provinc } \\
\text { e-5 }\end{array}$ & 10809 & $2,483.41$ & $11,604,285$ & 4,673 \\
\hline $\begin{array}{l}\text { Provinc } \\
\text { e-6 }\end{array}$ & 345 & 32.7 & $67,238.5$ & 28 \\
\hline $\begin{array}{l}\text { Provinc } \\
\text { e-7 }\end{array}$ & 2501 & 343.28 & $1,358,666$ & 3958 \\
\hline \begin{tabular}{l} 
Total \\
\hline
\end{tabular} & 44,722 & 11895.31 & $58,433,789$ & 4912 \\
\hline
\end{tabular}

\section{CHALLENGES}

There are many fish species that would be commercially and economically important but only few species are under culture in Nepal. The reasons behind this are lack of reaserch on the behaviour, propagation, population dynamics and biology of these indigenous species (Gautam, 2015). Furthermore, several challenges are faced by the fish farmers in Nepal. The major problem is the lack of sustainable fingerling supply system (Gurung et al., 2010). The farmers have faced the problem of lack of improved fingerling at stocking time especially in the rural areas that affect the aquaculture production. In addition, lack of marketing infrastructure, lack of cold storage facilities, poor quality fingerlings and fish feed and lack of technical knowledge are the major issues the fish industry is facing (Gautam, 2015). In pond aquaculture, lack of knowldege of proper pond management practice among farmers is also the major problem. Mantaining the water level, oxygen level, $\mathrm{pH}$, avoiding undesirable pollution residues for fish farming in pond aquaculture might also be challenging task for good and hygenic fish production. The natural disasters like flood in terai region and landslides in hilly region are the factors that affect the pond aquaculture production.

\section{CONCLUSION}

The production of pond aquaculture in Nepal is increasing annually with the growth rate of $4.64 \%$ in fiscal year $2017 / 18$ (CFPCC, 2018). People are constructing the ponds for fish farming by replacing the rice field in many parts of Nepal. From the trend of pond construction and production discussed above we can conclude that the pond aquaculture will further flourish in the future. Pond aquaculture is the first contributor to the aquaculture production in Nepal.Terai region of Nepal contributes the highest production to the pond aquaculture due to the suitability of land area, accessibility to developed infrastructures, availability of fingerlings etc. Among the seven provinces, province-2 contributes $57.75 \%(33,746,394 \mathrm{~kg})$ to the total production from pond aquaculture as there is highest pond number and area.

Among the various system practiced for pond aquaculture in Nepal, semi-intensive farming is the most common. The rearing of fish by enhnacing the growth of natural feed by supplying the fertilizer and additional feed is the most commonly practiced system in Nepal. However, the integration of horticulture crops and livestock rearing with the fish farming in pond is also being practied in Nepal.

Although the aquaculture is gaining popularity among the farmers, several challenges are being faced such as lack of adequate fingerlings, lack of technical knowledge, lack of developed market facilities, natural disasters like flood and landslides that result in the production loss to the farmers etc. To reduces this challenges in the future, the governemnt should make the plan and policy in fisheries sector of Nepal. The training related to the pond management practices should be conducted in community level. The fingerlings 
supply system should be managed well. The awareness programme to inform the farmer about the proper site selection to prevent the heavy loss due to natural disasters loke flood and landslides.

\section{REFERENCES}

[1] Andrea Katz. "The Role of Aquaculture in Nepal: Towards Sustainable Development." Ambio, vol. 16, no. 4, 1987, pp. 222-224. JSTOR, www.jstor.org/stable/4313363. Accessed 15 Aug. 2020.

[2] CFPCC. Annual book of fish. Machhapokhari, Balaju, Kathmandu: Government of Nepal; Ministry of Agriculture and Livestock Department, Department of Livestocks. Central Fisheries Promotion and Conservation Centre, 2018.

[3] Gautam, N. "Challenges of Freshwater Fisheries in Nepal: A Short Overview". International Journal of Applied Sciences and Biotechnology, Vol. 3, no. 4, Dec. 2015, pp. 579-83, doi:10.3126/ijasbt.v3i4.13524.

[4] Gurung, T. B., Mulmi, R. M., Klayan, K. C., Wagle, G., Pradhan, G. B., \&Upadhyaya, K. (2010). Cage fish Culture:An alternative livelihood option for communities display by reservior important in kulekhani, Nepal. In success stories in Asian Aquaculture, (pp.85-102) Springer Netherland

[5] Kunwar PS, Adhikari B. Status and development trend of aquaculture and fisheries in Nepal. Nepalese Journal of Aquaculture and Fisheries, 2016 \& 2017; volume 3\&4, page no.: 1-11

[6] Mishra RM. Status of aquaculture in Nepal. Nepalese Journal of Aquaculture and Fisheries, 2015; volume 2, page no.: 1-12

[7] National Aquaculture Sector Overview, Nepal. National Aquaculture Sector Overview Fact Sheets. Text by Pradhan, G. In: FAO Fisheries Division (ONLINE). Rome. Updated 10 October 2005. http://www.fao.org/fishery/countrysector/naso_nepal/en\#: :tex $\mathrm{t}=$ Aquaculture $\% 20$ is $\% 20$ fairly $\% 20 \mathrm{a} \% 20$ new, percent $\% 20 \mathrm{of} \% 2$ 0total\%20aquaculture\%20production.

[8] Shrestha MK, Pandit NP. A textbook of Principles of Aquaculture. Aquaculture and Fisheries Program; Agriculture and Forestry University, Rampur, Chitwan, Nepal, 2017.

[9] Shrestha MK. Aquaculture Development in Nepal and Current needs. UddhamSmarika, 2015; Page no. 14-15. http://www.cainepal.org.np/sites/default/files/Aquaculture\%20 Development $\% 20$ in $\% 20$ Nepal\%20and\%20Current $\% 20$ Needs $\underline{0 . p d f}$ 